\title{
A universidade como espaço de resistência a partir das instalações geográficas
}

\author{
${ }^{1}$ Anael Ribeiro Soares
}

${ }^{1}$ Universidade Federal do Cariri. E-mail: anael.rs@gmail.com

Recebido em 07/2013. Aceito para publicação em 10/2013.

Versão online publicada em 08/11/2013 (http://seer.ufrgs.br/paraonde)

\begin{abstract}
Resumo - 0 presente trabalho aponta no sentido de inovadoras práticas pedagógicas no ensino de geografia, de modo que propõe uma interface entre criatividade, arte, política e geografia de acordo com uma prática metodológica poiética. Reunimos através deste estudo parte de uma série de atividades realizadas ao longo de um ano proporcionadas pelo grupo de pesquisa Geografia e Criatividade, realizado na Universidade Regional do Cariri - CE. Em suma, as criações decorrentes das instalações e performances geográficas, corolário de um trabalho coletivo, fincam suas bases pedagógicas e ao mesmo tempo políticas no seio da Universidade, fazendo desta um espaço de resistência.
\end{abstract}

Palavras Chaves: Práticas Pedagógicas. Geografia e Criatividade. Universidade.

\section{Exórdio}

Ao pensar em ensino de geografia, invariavelmente, logo remontamos à mente inúmeras dificuldades imanentes a história do pensamento geográfico, e que consequentemente interferem no ensino/aprendizagem: dicotomia, paradigmas, metodologias, métodos, etc.

É incontestável que ainda existe um acervo de entraves, mas discorrer sobre tais seria um exercício de infindáveis lamurias: não nos propomos, com esse estudo, a um manancial de martírios! Tecemos outras reflexões que merecem destaque a priori, no que tange a educação e ao ensino de geografia, consubstancialmente a questão da Universidade no mundo globalizado, propondo, por fim, a construção de uma geografia da criatividade, segundo a qual tanto as instalações geográficas quanto performances possam na qualidade de arte política questionar modelo da Universidade em vigor.

Educar não é o ato adstrito de transmissão de saberes condensados em um dado "conhecimento", como num fluxo osmótico. Tampouco uma reprodução, geradora de um estigmatizado reprodutivismo acrítico, tanto no educador mais ingênuo, como no educando condicionado, característico do processo de refração de uma política educacional postergadamente falida ${ }^{1}$.

Contudo, nosso sistema educacional sempre assinalou práticas pedagógicas pautadas na memorização, repetição e transmissão de saberes isolados, sintetizados exclusivamente em livros didáticos. Aliás, nosso modelo de educação se dá num plano cingido, presidido no formato verboso, palavresco, em meros discursos, na maior parte das vezes dissidentes e antagônicos com a tendência de muitos que se dizem professores: de nada adianta o discurso competente se a ação pedagógica é impermeável a mudanças.(FREIRE, 1996, p.10).

A despeito do vagaroso avanço, nunca nos foi possível desvencilhar dessas máculas, remanescentes da pedagogia tradicional-autoritária. Por conseguinte, pesarosos, percebemos que o espaço escolar ainda é encarado, do ponto de vista dos educandos, como um ambiente que só proporciona o tédio, desconforto, desânimo, desinteresse, enfim, o silêncio absoluto. Como nos diz Kaercher (2003, p.32), "é sem dúvida, uma das lições mais eficientes que aprendemos na escola: o exercício do silêncio, a limitação da voz e criatividade dos alunos."

Portanto, é mais que necessário avançar e insistir em novas linguagens, sobretudo no ensino de geografia. Mas para tanto, lançamos mão à problemática: como transpor a geografia dos professores e dos Estados maiores nas palavras de Lacoste (2001), e ao mesmo tempo fazer do saber geográfico uma ferramenta política a nosso favor, através do exercício do ensino/aprendizagem nas práticas da nossa ciência geográfica, a fim de que evitemos as derrotas cristalizadas na condição espacial? Ora, embora saibamos que não há formas especificas para superar o geografismo, acreditamos que nossa tarefa direcionada ao ensino de geografia, se apresenta no despertar da criatividade, mediado pela

\footnotetext{
1 “Ensinar não é transferir conhecimento, mas criar as possibilidades para sua produção ou a sua construção.” (FREIRE, 1996, p.22)

${ }^{2}$ Por mais irônico que soe, é relativamente fácil deparar-se com aulas sobre democracia, cujas convicções do professor responsável por conferir considerem "como absurda e imoral" a participação do povo no poder. (Semelhante declaração, parafraseando Paulo Freire, foi constatada, aliás, com profunda tristeza em certas aulas conservadoras durante minha graduação do curso de geografia.)
} 
Soares.

arte, o lúdico, enfim, o novo, descoberto recôndito no íntimo do ato criativo, visto que "o novo não se inventa, descobre-se." (SANTOS, 2008, p.18).

Parece-nos que esse "novo", na linha do pensamento freiriano, ainda que com métodos distintos, corrobora, acima de tudo, "na modificação do conteúdo programático da educação, mas também com o método ativo, dialogal, crítico e criticizador; ademais também toma como suporte o uso de técnicas como a da dedução e codificação"(FREIRE, 2011a, p.141).

Entretanto, tudo que é novo, a princípio, sempre há de chocar, pois assombra aqueles que temem o diferente, os mesmo que possuem, peremptoriamente, uma "aversão fóbica a novidade e a mudança" (SOARES, 2001, p.38): são aqueles para os quais a realidade é inviolável, estática. A reprovação do novo, do diferente e mesmo do audacioso, a rigor, busca garantir a manutenção do status quo, condenando imperativamente iniciativa criadoras/criativas; tão logo, elas são vistas e apresentadas como perigosas, de modo que lhes aplicam sempre um dose de hostilidade, a fim de imobilizá-las.

Insistir no novo, naquilo que abarcar o esperançar, num salto para um horizonte mais nítido, é um meio de incremento ontológico do ser infinito e inacabado que somos, mas é também uma forma legítima de desmontar a alienação moral reinante, da qual o homem entrega-se a mais plena resignação, aceitando comedidamente a opressão sob o invólucro de virtude essencialmente humana: há tempos é incutida na mente dos oprimidos de "consciência intransitiva" que a obediência passiva é uma virtude axiológica. Ora, o ato de desobediência civil e moral - salvo algumas exceções por caracterizar o exercício da liberdade, é em si, um ato revolucionário... É um protesto ao comodismo, uma ofensiva ao fatalismo, a vitória do Ser mais.

Pois coadunamos com Lefebvre (2011, p.54), na seguinte declaração:

(...) as morais foram sempre ou sempre se transformaram em instrumentos de dominação de uma casta ou de uma classe social. (...) Foi a moral que criou a imoralidade desde o princípio, reduzindo ao domínio do imoral todo ato excepcional e obrigando-o a esconder-se nas sombras, na zona do anormal - e logo, porque as classes dominantes transmitiram sempre muito bem os valores que elas concebiam para o uso dos oprimidos.

Daí urge a necessidade de romper com que está posto, e incutido em no cotidiano, bem como em nossas consciências cumulativas, onde há feedback com o plano material: é eminente a necessidade de expurgar, de dentro para fora, o hospedeiro opressor introjetado no interior de nossas consciências. 0 novo, advogado aqui, portanto, busca oferecer as condições objetivas do desenvolvimento humano, bem como dá suporte a uma transformação social, quer seja por vias mais ousadas, quer seja mesmo por veredas mais discretas, desde que procurando despertar a consciência crítica, inserindo o sujeito no processo sócio-histórico-cultural, atribuindo-lhe um sentido existencial, por meio de uma geografia da criatividade. Nossa tarefa político-pedagógica nas vias do ensino de geografia inicia-se nas nossas práticas cotidianas, que enquanto educadores e educandos do ensino superior se dão a partir /através da própria Universidade. E, justamente, desde suas origens enquanto instituições formais - a princípio regidas diretamente pelo Estado incipiente e recentemente pelas "leis de ensino" e "sistemas pedagógicos" - tanto a Universidade quanto a escola sempre foram manipuladas como dispositivos políticos, cuja reprodução desigual já se encontrava embutida como lógica própria irredutível da causa. (BRANDÃO, C, R, 1995). Nessa perspectiva, é que através da instalação geográfica, mediados pela arte e a criatividade, saltou a necessidade de problematizar o modelo atual da Universidade.

A proposta dessa pesquisa implica em repensar outra Universidade, extrapolando o que se chama de liberdade acadêmica, ou mesmo o embuste da anunciada "autonomia universitária" - autonomia condicionada, dependente de agentes políticos. Na verdade, o que reclamamos subsidiados pela geografia da criatividade, de fato, foi uma Universidade com liberdade incondicional, sem qualquer censura ou restrição. Por outras palavras, postulamos uma Universidade fora do domínio da lógica do capital (do neoliberalismo, por exemplo), contudo, não por meio de reformas educacionais, tendo em vista o "(...) fato de as determinações fundamentais do sistema do capital serem irreformáveis."(MÉZAROS, 2008, p.26) A alternativa que apontamos, e buscamos suscitar com as criações poéiticas, foi exatamente no sentido de uma Universidade, assim como uma educação, para além do capital. (MÉZAROS, 2008).

A linguagem exercida no texto passeia pela poesia, arte e a geografia, isso se faz necessário quando se quer quebrar o que está posto, mesmo correndo os riscos quando o diferente apresenta-se aos olhos do tradicional. Mas é preciso romper sem perder o rigor acadêmico, necessário para apresentar a metodologia com as instalações geográficas. Entendemos a instalação como uma forma para expressar a construção de um determinado conhecimento trabalhado, com signos e símbolos. 0 termo instalação passa a ser incorporado ao vocabulário das artes visuais na década de 1960, designando ambiente construído em espaços de galerias e museus, prioritariamente, para mais tarde ganhar as praças, parques e as ruas públicas.

As instalações geográficas se constroem a partir de um conteúdo, que no nosso caso em questão é a universidade e a formação de novos professores para o ensino de geografia escolar, pensando criticamente o ensino superior. Qual é modelo de universidade atual? Que universidade almeja-se? Para quem afinal? Que prática pedagógica pode se inserir para apreendê-la, 
fazendo a critica pedagógica política? São perguntas que permeiam este estudo, mas que em nenhum momento foram exauridas por completo. E de certo modo, ainda permanecerão suspensas.

\section{Em busca da criatividade no ato educativo}

Uma parte de mim é só vertigem: outra parte, linguagem. Traduzir uma parte na outra parte - que é questão de vida ou morte - será arte?

(GULLAR, 2004, p.169)

0 ensino aprendizagem vigente ainda preza pelo $\operatorname{logos}^{3}$ como valor máximo, em detrimento da arte. Para Nietzsche (1844-1900), contudo, ao repelir a arte, a educação suplanta a própria vida. Segundo sua concepção, a educação deve ir além do conhecimento em si, quer dizer, estéril, somente focado na erudição. Remontando as origens da Filosofia, podemos tomar como conclusão, que a ideia socrática alicerçada na lógica formal de que "o homem é um ser racional" está no mínimo incompleta, pois, igualmente, ele é um ser essencialmente emocional, em seu aspecto estético, e isso jamais deve estar subjacente.

No pensamento de Nietzsche(2005), se o apolíneo expressa uma arte bela, perfectível, sistemática, de outro modo o dionisíaco assinala uma nova arte, situada na subjetividade da beleza, anunciadora de uma verdade pungente ${ }^{4}$. 0 termo dionisíaco tem sua origem na figura do deus Dionísio. Aqui vem ao caso, inclusive a fim de já explanar acerca da relação entre imaginação e experiência (cotidiano), isto é, entre a transição das imagens fantasiosas e a imaginação cristalizada, ou em síntese, do processo do ato criativo, pôr em relevo ligeiramente algumas palavras centrais no que toca as origens mitológicas desse deus tão eminente na filosofia nietzschiana.

Segundo Brandão (1999), há duas versões que explicam a origem de Dionísio ${ }^{5}$ (Baco). Na primeira, ele advém da traição de Zeus com Perséfone. Após uma crise de ciúme, Hera, esposa de Zeus, envia os Titãs para perseguir Dionísio e ao encontrarem eles então o estraçalham e devoram-no sem piedade. Mas Zeus tomado pela ira lança raios aos Titãs até restarem deles somente às cinzas, resgatando o coração do filho, e fazendo surgir das cinzas dos Titãs os homens.

Ainda assim, Zeus volta a trair Hera, só que dessa vez com Sêmele. Como resultado dessa segunda traição nasce outro Dionísio, em virtude do coração conservado do outro filho devorado pelos Titãs. Mais uma vez Hera descobre a traição e articula um plano para matar o filho bastardo ainda no ventre de Sêmele. Hera conse- gue matar Sêmele, porém Zeus salva o filho transferindo-o para sua coxa a fim de que fosse concluída a gestação. Desde então, Dionísio assumirá outras formas por meio do metamorfoseamento para fugir da tirania de sua madrasta, por vezes até sucumbindo diante do encalço, mas não por acaso, amiúde volve a vida, afinal detinha ele, enquanto deus, o dom da imortalidade. Enquanto deus da vegetação, tal qual sua genuína mãe, Dionísio estava sempre ladeado por plantas das mais diversas espécies, dentre elas a uveira.

Num determinado evento, o deus tem a oportunidade de deleitar-se com o suco de uvas extraído do Monte Nisa, na companhia dos sátiros e das Ninfas; excitados pela melodia dos címbalos, todos começam a dançar de modo disparatado ao ponto de suas forças serem totalmente exauridas. É daí que brotam os cultos em nome de Dionísio. Por outras palavras, é através de toda combinação desses elementos fantásticos da mitologia, da relação deles com a experiência, que se dá origem a um fenômeno que corresponde à própria realidade grega: os festejos em comunhão com o deus Dionísio, baseados na orgia e na mania, estas, aliás, diz Brandão (1987, p.136), “(...)provocavam uma como que explosão de liberdade e, seguramente, uma transformação, uma liberação, uma distensão, uma identificação, uma kátharsis, uma purificação."

O mito de Dionísio, como produto da imaginação, nesse caso acaba por servir de bom grado a experiência. Elava-se uma questão neste ponto, primordial se, de fato, quisermos atentar para a reciprocidade estabelecida imaginação e criatividade(ato criador), de que forma uma encontra-se em íntima relação com outra, num jogo ruidoso de implicância mútua. Nosso ponto de apoio não poderia ser outro senão a psicologia da aprendizagem, especificamente sob a abordagem sócio-interacionista.

Vigotski (2009) assevera que, de modo geral, existem pelo menos quatro prerrogativas que conduzem a relação entre atividade criadora e experiência. Eis as formas pelas quais a imaginação se apóia na experiência ao mesmo tempo em que esta se apóia naquela, de acordo com Vigotski(2009, p.20-34):

- A primeira forma de relação entre imaginação e realidade consiste no fato de que toda obra de imaginação constrói-se sempre de elementos tomados da realidade e presentes na experiência anterior da pessoa;

- A segunda forma de relação entre fantasia e realidade é diferente, mais complexa, e não diz respeito à articulação entre os elementos da construção fantástica e a realidade, mas sim àquela entre o produto final da fantasia e um fenômeno complexo da

\footnotetext{
${ }^{3}$ No grego, logos exprime "palavra", mas estritamente na história da filosofia, adquiri significado amplo, associado ao sentido de razão. ${ }^{4} \mathrm{O}$ sentido de verdade aqui, não encontra significado na acepção socrática, e sim na noção efusiva do sofrer, da dor, dos sentimentos mais profundos, numa visão bem nietzchiana de verdade.

${ }^{5}$ Em algumas obras do Nietzsche verifica-se ainda o emprego do termo "Dioniso", mas aqui, a título de coerência linguística, optamos pelo termo "Dionísio".
} 
da realidade;

- A terceira forma de relação entre a atividade de imaginação e a realidade é de caráter emocional. Ela manifesta-se de dois modos. Por um lado, qualquer sentimento, qualquer emoção tende a se encarnar em imagens conhecidas correspondentes a esse sentimento;

- Resta ainda mencionar a quarta e última forma de relação entre fantasia e realidade. Por um lado, essa forma liga-se intimamente a que acabamos de descrever, mas, por outro, diferencia-se dela de maneira substancial. A sua essência consiste em que a construção da fantasia pode ser algo completamente novo, que nova aconteceu na experiência de uma pessoa e sem correspondência com algum objeto de fato existente; no entanto, ao ser externamente encarnada, ao adquirir uma concretude material, essa imaginação "cristalizada", que se fez objeto, começa a existir realimente no mundo e a influir sobre outras coisas.

Sem dúvida, que qualquer uma das quatro relações poderiam ser exploradas de modo mais acurado dentro do nosso raciocínio, dada a pertinência no que toca a criatividade. Contudo, enfocar-se-á substancialmente está última relação, diluída num quatro analítico doravante.

Tomemos de exemplo o obra Guernica de Pablo Picasso. Sabe-se que a obra foi fruto de uma encomenda do Governo Republicano Espanhol, que solicitou ao artista a retratação dramática das conseqüências do fascismo no decorrer da guerra civil espanhola. A pintura faz alusão à destruição da cidade Guernica, portanto ainda que pictórica, e completamente inverossímil, refere-se a um dado fato histórico. Picasso consegue traduzir pictoriamente, numa sublimação, os elementos da realidade que o cercava, reelaborando-os numa atividade combinatória, até que "finalmente, ao se encarnarem, retornam a realidade, mas já como uma nova força ativa que a modifica. Assim é o círculo completo da atividade criativa da imaginação."(VISGOTSKY, 2009, p.30). Verifiquemos, pois, como tudo isso se transfere para termos pedagógicos e educacionais.

0 que chamamos de criação, na esteira do ato criador, nada mais é do que uma resultante do processo complexo de sentimentos coletivos gestados ao longo de um período relativamente longo, do qual o escopo causal é a externalização de tudo aquilo que foi internalizado nas vias das impressões empíricas, e desenvolvido na fase de incubação. Concluí-se que a criação, por excelência, é um processo combinatório interno e externo que encarna e culmina numa matriz central: no cotidiano (experiência).

Enquanto imaginação cristalizada, a criatividade é exatamente a que põe abaixo o cotidiano educacional vigente, qual seja, os envelhecidos muros da escola e da Universidade hermética, poetizando a vida cotidiana, invadindo a sua programação "cíclica" a partir de uma força dionisíaca, enfocando um conhecimento útil, que se inicie e tenha respaldo na vida prática, no cotidiano vivido:

A partir das relações do homem com a realidade, resultantes de estar com ela e de estar nela, pelos atos de criação, recriação e decisão, vai ele dinamizando o seu mundo. Vai dominando a realidade. Vai humanizando-a. Vai acrescentando a ela algo de que ele mesmo é fazedor. Vai temporalizando os espaços geográficos. (FREIRE, 2011, p.60.)

Por várias das vezes, se ouve que o educando deplora um suposto deslocamento quando precisa concatenar-se a determinado assunto indiferente a sua vida cotidiana, é porque para ele, o conhecimento só tem sentido se implicar de alguma maneira em seu comportamento, na sua concepção de mundo, e especialmente em sua realidade: "Há um desejo que a escola seja útil, direta e imediatamente, às suas vidas." (KAERCHER, 2003, p.32.). Em razão disso, se faz necessário que a imaginação(pensamento) do educando esteja intrinsecamente construída em torno de sua realidade, haurindo os elementos que a constitui, a fim de que, reelaborados na atividade combinatória, atuem no comportamento e desenvolvimento humano, até tomar forma, estrutura e essência com objetividade integrada na realidade, dinamizada pela produção coletiva.

Falha a abordagem educacional que postula a busca incessante por um elevado grau de erudição, cujo valor esteja desprovido de um ideal objetivo, de um sentido existencial. 0 conhecimento pautado na criatividade não está de acordo com o sujeito erudito que muito pensa, e que nada faz para objetivar seu pensamento:

É falso pretender que a educação trabalhe o corpo e a inteligência de sujeitos soltos, desancorados de seu contexto social na cabeça do filósofo e do educador, e que os aperfeiçoe para "si próprios", desenvolvendo neles o saber de valores e qualidades humanas tão idealmente universais que apenas existem como imaginação em toda parte e não existem como realidade (como vida concreta, como trabalho produtivo, como compromisso, como relações sociais) em parte alguma. (BRANDÃO, R, C, 1995, p.70)

A educação, destarte, não pode jamais ser um mero meio objetivando fornecer uma função social ao sujeito, esse fito apenas produz uma atrofia intelectual: diferentemente, deve suscitar um infindável "Porquê" sempre mesclado a uma forma de "Querer". E a atividade criadora traduzida na imaginação cristalizada é uma forma de significar, dentro do campo semântico, o despertar da consciência da realidade cuja lucidez implica no desejo de transcendê-la, a fim de atuar no cotidiano 
vivido orientado por um télos.

"Nesse sentido, o exercício teorizante só pode ser verdadeiro se se tornar ação."(ARAUJO, 2008, p.44). Pois a criatividade exprime, em seus estímulos originários, bases teleológicas sem as quais não haveria sentido algum na criação, necessidade e desejo, são apenas forças propulsoras que desencadeiam um processo que tende a ganhar ritmo na medida em que se choca com as condições materiais revestidas de um exercício afetivo.

Assim, estabelecer práticas pedagógicas a partir da criatividade permite subverter, revirar ao avesso a estrutura educacional vigente baseada na lógica cartesiana, "(...) prenhes de valores capitalistas (pontualidade, obediência, trabalho mecânico/repetitivo)" (SOARES, 2001, p.24), crivando de vivacidade a escola que padece em suas formas e conteúdos, metamorfoseando, como resultado desse processo, os espaços cotidianamente vividos. Professores e alunos deixam de ser "cadáveres adiados que procriam", aludindo Fernando Pessoa, acorrentados aos programas e práticas do sistema educacional, instituído sobre a concepção de uma educação bancária ${ }^{6}$, de conotação positivista, reduzindo-se a opressão do falar-ditar e calar-ouvir. 0 educando já não pode nem deve ser reconhecido pelo educador como um recipiente, um "objeto", como numa relação vertical. Pelo contrário, precisa ser encarado, antes de tudo, como sujeito (outro-eu), a partir de uma relação de alteridade, ou melhor, de outridade.

O Educador, por sua vez, distancia-se das respostas, torna-se amante devotado dos questionamentos. Sendo ele Educador autêntico, na sua prática docente, munido de uma práxis libertária, atua como guia, lança situações provocadoras, instigantes, desafiadoras, que exigem das múltiplas inteligências do Educando, ao passo em que este, abandona seu estado de passividade - copiando ou ouvindo -, para através da "curiosidade epistemológica", (FREIRE, 2011a) do ato provocativo/crítico emergido, tornar-se co-autor na produção do conhecimento. $\mathrm{O}$ conhecimento, assim considerado, aflora na relação dialética, no diálogo.

A passividade já não é mais aceitável comedidamente. É imperativo assombrar-se, aventurar-se, criar na prática docente, enquanto se tem a voz e a criatividade ao alcance, posto que tanto a liberdade de falar quanto o ato da criação podem ser - se é que já não o está sendo- sumariamente suprimidos. Eduardo Alves da Costa, em seu célebre No caminho, com Maiakóvski, lembra-nos poeticamente da necessidade em antecipar-se, no despertar e agir o quanto antes:
Para Onde!?, 7 (1): 25-33, jan./jul. 2013 $\mathrm{Na}$ primeira noite eles aproximam-se e colhem uma flor do nosso jardim e não dizemos nada. Na segunda noite, já não se escondem; pisam as flores, matam o nosso cão, e não dizemos nada. Até que um dia o mais frágil deles entra sozinho em nossa casa, rouba-nos a lua e, conhecendo o nosso medo, arranca-nos a voz da garganta. E porque não dissemos nada, já não podemos dizer nada. (COSTA, 2001, p.218)

Urge, portanto, na relação educador/educando no ensino de Geografia, um fio condutor que transmita uma metodologia dialética e criativa, segundo a qual o educando tenha voz e liberdade artística, fazendo com que a geografia avance em lugar de estagnar em discussões estéreis ou em ideias inertes? ${ }^{7}$.

\section{A universidade como espaço de resistência a partir das instalações geográficas}

As instalações geográficas que constituem este trabalho, conforme o conceito elaborado por Ribeiro $(2009,2011)$ segue - em partes - as seguintes etapas metodológicas:

- 0 ato criativo, no que diz respeito à instalação geográfica, enquanto forma materializada (forma do objeto) pressupõe um conteúdo(mental) que não está no efeito do ato, isto é, no objeto em si(social) ${ }^{8}$, como algo inato; é imputada a forma um significado de modo associativo, ou seja, o que compõem a estrutura do objeto não passa de uma representação que se associa ao que está sendo representado;

Mas para tanto, antes, faz-se necessário conjeturar reflexões, estudos, pesquisas, métodos, logrando assim, a práxis tão almejada. Por isso, o processo que antecede a prática da instalação geográfica, é de base inteiramente teórica, reflexiva. E esta instalação geográfica, ao seu término, já inicia outro processo que pode ter uma finalidade didática, perceptiva, avaliativa ou mesmo construtivista:

Para a criação temos uma forma, um conteúdo, que exige recursos e condições para o momento do devir, esta forma, antes de se realizar passa pela sensibilidade, pelo toque, pelo intelecto, pelo ato de intuir que se faz presente no cotidiano que muitos intelectuais desprezam, é preciso ter um olhar mais preciso para o cotidiano para o vivido. (RIBEIRO, 2011, p.63)

\footnotetext{
6 "Educador e Educando se arquivam na medida em que, nesta distorcida visão da educação, não há criatividade, não há transformação, não há saber." (FREIRE, 2011b, p. 81)

7 "Ideias inertes, quer dizer, ideias que a mente se limite a receber sem que as utilize, verifique ou as transforme em novas combinações." (WHITEHEAD apud FREIRE, 2011a, p.122)

${ }^{8}$ Forma do objeto (prática-sensível) Mentalmente: 0 equilíbrio interno percebido e concebido como propriedade "objetiva” (ou “objetal”) de cada objeto e de todos. A simetria. Socialmente: a espera desse equilíbrio e dessa simetria, exigida dos objetos ou por eles desmedida (compreendendo-se, entre esses objetos, os "seres" vivos e pensantes, bem como objetos sociais tais como casas, edifícios, utensílios, instrumentos, etc.). (LEFEBVRE, 2001, p.90)
} 
- Assim, todo esse processo perpassa a análise, organização, observação, projeção, descrição, por parte dos educandos no momento anterior e posterior a instalação geográfica, e demanda decodificação, reflexão, leitura dialética e síntese em relação ao público (outros estudantes; professores, funcionários, transeuntes em geral);

O conhecimento, concebido através da criatividade, compreendida no plano dos sentimentos, sobretudo da criação, é assimilado num movimento de absorção concomitantemente a prática de extroversão, num fluxo intersubjetivo, irredutivelmente, sem cessar, ${ }^{9}$

Portanto para compreender a criatividade e processo de criação alguns estudos são necessários, a ato criativo não surge do nada, não é inato, ele é construído, é parte de um processo que se traduz numa obra, seja de arte, livro ou em novas descobertas científicas, são elementos, que compõem o espaço social e a natureza, que se dá no plano do vivido. (RIBEIRO, 2011, p.62)

- A investigação do tema (no caso, universidade) é o limiar do processo de elaboração da instalação geográfica. 0 princípio do tema introverte uma ou mais problemáticas, as quais sejam reflexos das contradições da condição sócio-espacial, a partir de um ato político-educativo da consciência de seus formuladores;

Amparados por Freire (2011), podemos compreender esses temas como "temas geradores", cuja origem transparece uma situação-limite, a fim de dar suporte aos atos-limites ligados a percepção fronteiriça entre a margem do Ser e o Ser mais.

- A etapa da pesquisa consiste no levantamento bibliográfico do tema que se pretende materializar na instalação geográfica, sempre se considerando os contextos, isto é, as condições sócio-espaciais locais em relação à vida cotidiana. Aqui algumas técnicas podem ser adotadas, tais como: observação, entrevista não-estruturada, questionários;

Nesse primeiro momento, é imprescindível a orientação e o planejamento, pois ao contrário do que se pensa, "exercer a criatividade não é deixar os alunos soltos a vontade, sem indicar um caminho, é preciso orientação, direcionamento, conteúdo, objetivo, insistência no ato a ser criado." (RIBEIRO, 2011, p.67).

É preciso salientar que, quer seja uma instalação geográfica individual, quer seja coletiva, o resultado deve corresponder à visão de mundo e ao nível de consciência dos educandos, porque ao passo em que o educador interfere na instalação, em vez de orientar, implica, com essa postura, numa invasão cultural. Assim, o educador, na verdade, estaria incorrendo ainda que inconscientemente, na consolidação da educação bancária e não na instauração da libertária.

- Não há, de fato, um método rigoroso (engessado) no processo de construção da instalação geográfica. Os métodos observam as condições sócio-econômicas de acordo com os objetivos, de modo que o único dispositivo eficiente acaba sendo a criatividade e o improviso - considerando devidamente a particularidade dos casos estudados. Nesse sentido, os materiais usados fazem parte do próprio cotidiano dos educandos, o que vem a ser bastante positivo, posto que, do contrário, recursos consideráveis seriam empreendidos na empreitada. Os materiais usados nas instalações deste trabalho foram: papelão, rosas ornamentais, estrume, fitas adesivas, um manequim, um funil, linhas, plásticos e um espelho;

- As instalações geográficas aqui apresentadas foram fixadas na Universidade Regional do Cariri, no interior do Ceará, no momento onde ocorriam dois eventos distintos realizados no ano de 2012: XXII Encontro de Estudantes de Geografia do Ceará e III Colóquio de formação docente;

No decorrer do processo de elaboração, por um lado cabe aos educandos, na condição de sujeitos, a pesquisa e estudo do tema, dos materiais, do método. Por outro lado, é papel do educador o acompanhamento, orientando e auxiliando quando necessário. Com efeito, "nas condições da verdadeira aprendizagem os educandos vão se transformando em reais sujeitos da construção e da reconstrução do saber ensinado, ao lado do educador, igualmente sujeito no processo." (FREIRE, 1996, p.26).

A princípio, antes de enfocar as instalações geográficas propriamente ditas, gostaríamos de pôr em relevo uma problemática contundente: o que vem a ser a Universidade? Saviani (2009), conotativamente, afirma que as repostas comuns poderiam ser "multiplicadas ao infinito": "É o lugar da cultura"; "Reunião de escolas da ordem mais elevada, cujo ensino abrange todos os ramos da instrução superior"; "Organização destinada ao ensino superior", composta de número variável de escolas ou faculdades"; "Instituição destinada à conservação, criação, transformação e transmissão da cultura”. Nenhuma delas, contanto, conseguem ultrapassar a abstração pueril, uma vez que prescindem "o produto do produtor", ou seja, não concebem o processo que implica na existência da Universidade.

No sentido prático, desconsiderando discussões de cunho legislativo, e levando em conta pesquisas com

${ }^{9}$ RIBEIRO, Emerson. A Criatividade em Geografia, Prática Pedagígica e Avaliação: Laternas Geográficas, Geosaberes, Fortaleza, v.2, n. 4, p. 61- 74, 2011. 
abordagens sociológicas ${ }^{10}$, diante de uma postura crítica concernente ao processo gerador, no papel de educadores e educandos, o que é hoje afinal a Universidade, compreendida como fundamento causal da realidade social, senão um dispositivo político subsidiado por órgãos de fomento, e por isso, um instrumento sujeito aos poderes visíveis e invisíveis do Estado, aos ditames econômicos, midiáticos e ideológicos? A dependência da Universidade expõe sua fragilidade, o que acaba por torná-la uma mera sucursal do Estado, das corporações, tal qual uma extensão político-econômica, ao em vez de firmar-se como uma instituição imune, detentora de uma liberdade incondicional, como defende Derrida (2003, p32).

Pesquisa é o princípio capital da existência e razão mantenedora da universidade, ciclo renovador do ensino e fonte de aprendizagem, que estabelece um “(...) diálogo crítico e criativo com a realidade, culminando na elaboração própria e na capacidade de intervenção."(DEMO; 2009; p.128). Ocorre que o professor-pesquisador se depara com uma série de estorvos no ato da pesquisa: ausência de recursos, desvalorização da categoria, ausência ou inadequação de espaços para instrumentalização da pesquisas (bibliotecas, laboratórios, salas de planejamento), política científica intransigente. No fundo, tudo isso implica na falta de vontade política. E a Universidade, aos poucos, vai sendo invadida por um poder estranho, que se apropria e condiciona (quase) todas as iniciativas que tenham origem nela. Com tudo isso, propugnamos aqui, que essa tal Universidade encontra-se em crise, pois passa por um momento de transição, cujas mudanças se dão por meio de um jogo ruidoso de forças, relações de poder que inauguram um território em disputa. De um lado, o poder estatal invade arbitrariamente a Universidade ao passo que esta vai perdendo autonomia, e sendo instrumentalizada para fins político-econômicos, mas por outro lado, aflora uma resistência, que se instala com arte, política e criatividade.

As condições da atual Universidade trazem a baila, por conseguinte, inúmeras dúvidas, medos, desafios, que julgamos ser de suma importância espacializar, a fim de que não continuassem habitando tão somente o campo da imaginação, mas que se tornassem uma imaginação cristalizada decorrente de um ato criador $^{11}$.

Deste modo, decidimos após incansáveis debates no grupo de estudos Geografia e Criatividade, realizado na Universidade Regional do Cariri, Ceará, iniciar uma série de intervenções nessa mesma instituição. Intervenções estas que já conhecemos pelo nome de instalações geográficas, cuja proposta inicial seria materializar, de modo codificado, desafios, dúvidas, problemas, questões que ameaçam a Universidade no mundo globalizado. Questões, inclusive, semelhante aquela levantada por Derrida (2012, p.21): "pode a Universidade (e de que maneira?) afirmar uma independência incondicional, reivindicar uma soberania, uma espécie bem original, uma espécie excepcional de soberania, sem nunca se arriscar ao pior, a saber, em função da abstração impossível dessa soberania independência, ter que se render e capitular sem condição, deixar-se conquistar ou comprar a qualquer preço?"

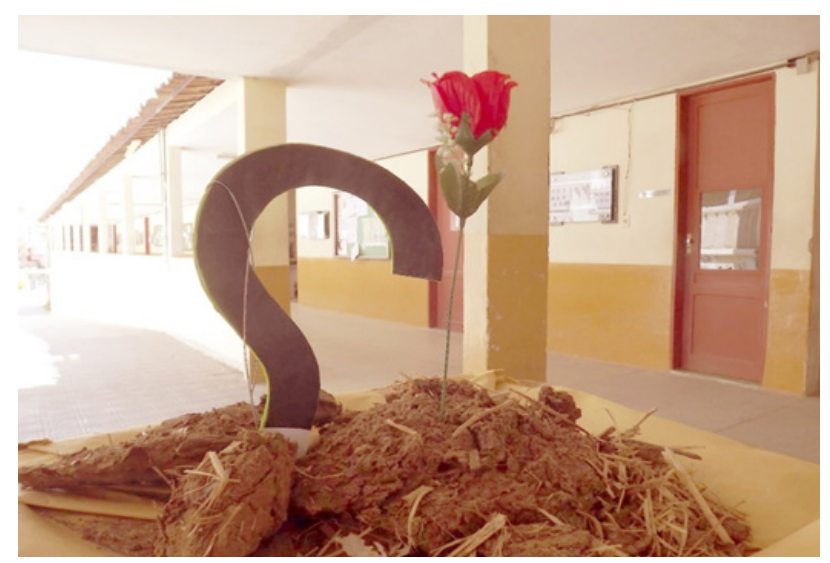

Figura 1: Instalação Geográfica realizada em meio ao Encontro de Estudantes de Geografia do Ceará, sediado pela Universidade Regional do Cariri, no ano de 2012.

Fonte: Alexandre Lucas

Inspirados por Soares (2001, p.30), ainda crivamos as seguintes palavras na instalação supracitada: Os mofos, as varizes e as manchas desse velho prédio é uma identificação clara das feridas que dilaceram a educação.

Na mesma linha de pensamento, a instalação a seguir trata-se de uma crítica a especialização, segundo a qual os educadores/pesquisadores precisam enfocar uma subárea cada vez mais restrita do conhecimento, desde a graduação, passando pelo mestrado, até o doutorado, se "sabe cada vez mais de cada vez menos, até saber-se tudo de nada ${ }^{12 " .}$

Manifesta, acima de tudo, uma inquietude no diz respeito à educação elitista, seletiva, que legitima e consolida a estrutura social classista: uma educação desumanizadora que encaminha para o mercado (competitividade, individualismo, aperfeiçoamento compulsório), e não para compreensão da vida em toda sua complexidade social, aonde possa ser possível estruturar as capacidades criativas e os potenciais emancipatórios do sujeito.

Nós últimos anos no Brasil, a educação pública vem sendo cada vez mais desqualificada e sofrendo diversos ataques em função do modelo socioeconômico

\footnotetext{
${ }^{10}$ DERRIDA, Jaques. A Universidade sem condição. 1.ed. São Paulo: Estação Liberdade, 2003. 88 p.

LECHER, Roberto. Do discurso e das condicionalidades do Banco Mundial, a educação superior "emerge" teciária. Revisa Brasileira de Educação, Brasil, v.13, n.39, p.423-437, 2008.

${ }^{11}$ Consultar VIGOTSKI, Lev S. Imaginação e criação na infância: ensaio psicológico: livro para professores. 1.ed. São Paulo, Ática, 2009. p.11-42.

${ }^{12}$ Frase célebre de George Bernard Shaw.
} 
Soares.

adotado. 0 reflexo disto constata-se na reelaboração ilegítima dos estatutos das Universidades, no sucateamento do ensino público de modo geral, na desvalorização do professor, nas greves que irrompem constantemente, sejam em escala municipal, estadual ou nacional, e ao mesmo tempo, com efeito, na abertura para expansão do ensino privado orientada por necessidades estabelecidas pelo mercado mundial - isso sendo bem lacônico. Tal conjuntura faz parte de um projeto geopolítico mais complexo, vinculado as forças de mercado globais regidas e cadenciadas, principalmente, pelo Banco Mundial, provocando "um verdadeiro apartheid educacional planetário". (LECHER, 2008, p.428.)

A instalação a seguir corresponde, pois, a nossa crítica: a que e sobretudo a quem o sistema educacional brasileiro vem servindo(?). Mas por outro lado, em arremate, encontra sentido nas palavras vigorosas de Mészáros(2010), em uma passagem da concisa em volume mas grandiosa em conteúdo Educação para além do capital:

A educação institucionalizada, especialmente nos últimos 150 anos, serviu - no seu todo- ao propósito de não só fornecer os conhecimentos e o pessoal necessário à máquina produtiva em expansão do sistema do capital, como também gerar e transmitir um quadro de valores que legitima os interesses dominantes, como se não pudesse haver nenhuma alternativa a gestão da sociedade, seja na forma "internalizada" (isto é, pelos indivíduos devidamente "educados" e aceitos) ou através de uma dominação estrutural e uma subordinação hierárquica e implacavelmente impostas.(MÉSZÁROS, S, 2010, p.35)

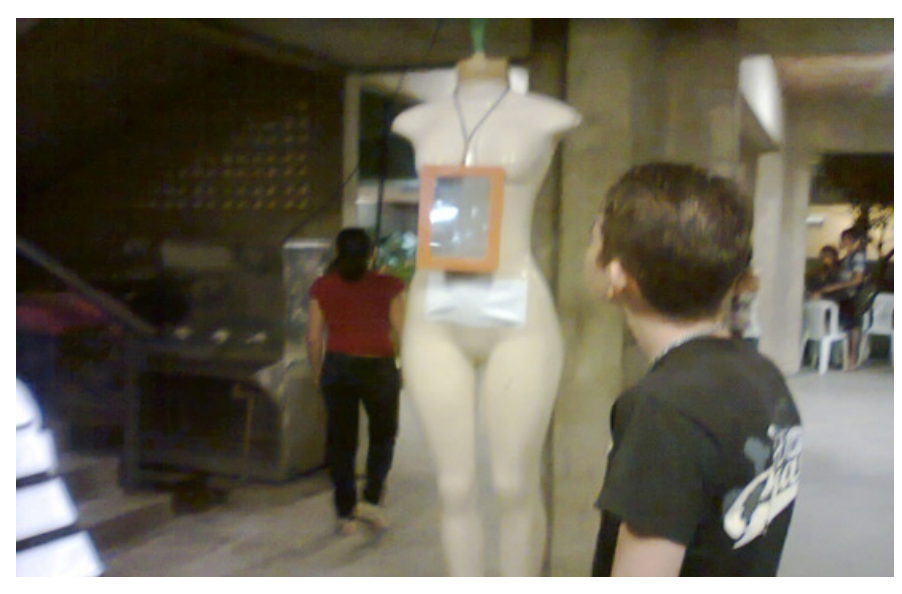

Figura 2: Instalação Geográfica realizada em meio ao III Colóquio de formação docente, na Universidade Regional do Cariri, no ano de 2012

Fonte: Emerson Ribeiro

É mais que eminente o afloramento de novas maneiras criadoras de se pensar, conceber e fazer o conhecimento (geográfico) pulsar na universidade, na escola e principalmente para além destas, a favor da cons- cientização política dos que hoje se encontram imersos na cotidianidade, hospedando inconscientemente, na mais cruel contradição, seu opressor. Em outras palavras, é de caráter capital a construção de nova Pedagogia do Oprimido. E o que fazer, ou melhor, como fazer? Há alternativa? É impossível apontar um caminho, uma receita. Mas sem dúvida, alternativas existem, e uma delas é "minando as bases estruturais do complexo ideológico escolar dominante, [sic] uma arte de rebeldia, mas assertiva criadora, é o uso da poesia."(SOARES, 2001, p.43)

Fundados em maneiras criadoras para o conhecer (e fazer) geográfico, numa tática de antecipar o possível, e ampliar as possibilidades do denevir, preterimos a lógica do capital arraigado na Universidade, ferindo-a ao extrair as problemáticas a ela inerente, a partir da influência do ciclo da atividade combinatória materializada em novas linguagens, formas, ritmos, consideradas por uma lado subversoras perante lógica educacional mercadológica, mas por outro revolucionárias no âmago da perspectiva critica.

\section{Considerações finais}

Notamos que em ambas as instalações nosso objetivo fora logrado, uma vez que ao fomentar a curiosidade, a decodificação e a dialética, como proposta pedagógica na construção de uma geografia da criatividade, engendramos assim, o pensamento crítico no seio da universidade, fazendo desta, ainda que gradualmente, um espaço de resistência.

Em síntese, as instalações geográficas fixadas na Universidade Regional do Cariri, Ceará, em momentos específicos, em essência, tiveram como objetivo manter pulsando o pensamento crítico instigado pela arte e a criatividade, de estabelecer a resistência política a favor de uma Universidade com liberdade incondicional, de metamorfosear as manchas, mofos, rachaduras, em poesia viva.

Abstract - This work points towards innovative teaching practices in the teaching of geography, so that proposes an interface between creativity, art, politics and geography according to a methodological practice poietic. We gathered through this study starts with a series of activities over a year provided by the research group Geography and Creativity, held at the University of Cariri Regional - EC. In short, the creations resulting from installations and performances geographical corollary of a collective work, fincam pedagogical bases while policies within the University, making this an area of resistance.

Key Words: Pedagogical Practices; Geography and Creativity; University.

Resumen - Este trabajo apunta hacia prácticas pedagógicas innovadoras en la enseñanza de la geografía, por lo que propone una interfaz entre la creatividad, el arte, la política y la geografía de acuerdo con una práctica poiética metodológica. Nos reunimos a través de este estudio se inicia con una serie de actividades a lo largo de un año previsto por el gru- 
po de investigación de Geografía y Creatividad, celebrado en la Universidad de Cariri Regional - CE. En resumen, las creaciones resultantes de instalaciones y actuaciones geográfica corolario de un trabajo colectivo, las bases pedagógicas fincam mientras que las políticas dentro de la Universidad, haciendo de este un espacio de resistencia.

Palabras Clave: Prácticas pedagógicas, Geografía y Creatividad; Universidad.

\section{Referências}

ARAUJO, José Carlos de Souza. 0 embate marxiano com a construção dos sistemas educacionais. In: LOMBARDI, José Claudinei; DERMEVAL, Saviani. Marxismo e educação: debates contemporâneos. 1ed. São Paulo: Autores Associados, 2008. p. 39-68.

BRANDÃO, Junito de Sousa. Mitologia Grega. 1.ed. vol. II. Petrópolis: Vozes, 1987.323 p.

BRANDÃO, Carlos Rodrigues. 0 que é educação. 33.ed. São Paulo: Brasiliense, 1995. 116 p.

DEMO, Pedro. Desafios Modernos da Educação. 15.ed. Petrópolis: Vozes, 2009. 272 p.

DERRIDA, Jaques. A Universidade sem condição. 1.ed. São Paulo: Estação Liberdade, 2003. 88 p.

FREIRE, Paulo. Educação como prática da liberdade. 14.ed. Rio de Janeiro: Paz e Terra, 2011a. 158 p.

Pedagogia da Autonomia: saberes necessários à prática educativa. 33.ed. São Paulo: Paz e Terra, 1996. 143 p.

. Pedagogia do Oprimido. Rio de Janeiro: Paz e Terra, 2011b, 50. ed. 213 p.

GULLAR, Ferreira. Melhores poemas de Ferreira Gullar. 7.ed. São Paulo: Global, 2004. 290 p.

KAERCHER, Nestor. Desafios e utopias no ensino de Geografia. 2.ed. Rio Grande Sul: Edunisc, 2003. 144 p.

LACOSTE, Yves. A Geografia-Isso serve em primeiro lugar para fazer a guerra. 5.ed. São Paulo: Papirus, 2001. $263 \mathrm{p}$.

LECHER, Roberto. Do discurso e das condicionalidades do Banco Mundial, a educação superior "emerge" teci- ária. Revisa Brasileira de Educação, Brasil, v.13, n.39, p.423-437, 2008.

LEFEBVRE, Henri. Marxismo. 1.ed. Porto Alegre: L\&PM, 2011. 128p.

LEFEBVRE, Henry. 0 direito à cidade. 2.ed. São Paulo: Centauro, 2001.145 p.

MÉSZÁROS, Istvam. A Educação para além do Capital. São Paulo: Boitempo, 2008. 126 p.

NIETZSCHE, Friedrich. A visão dionisíaca do mundo e outros textos de juventude. 5.ed. São Paulo: Martins Fontes, 2005. 93 p.

RIBEIRO, Emerson. A Criatividade em Geografia, Prática Pedagígica e Avaliação: Laternas Geográficas, Geosaberes, Fortaleza, v.2, n. 4, p. 61- 74, 2011.

Práticas Pedagógicas - o ensino geográfico por instalações. In: IX SEMINÁRIO DE PÓS-GRADUAÇÃO EM GEOGRAFIA DA UNESP, 9., 2009, Rio Claro. Anais... Rio Claro: UNESP, 2009.3 v. p. 556-569.

AVALIAÇÃO OU PESCARIA? Por uma distinta possibilidade da aprendizagem em Geografia na construção de instalações geográficas. Revista Brasileira de Educação em Geografia, Rio de Janeiro, v. 1, n. 2, p. 91104, 2011.

COSTA, Eduardo Alves. No Caminho, com Maiakóvski. In: PINTO, José Nêumanne. Os Cem Melhores Poetas Brasileiros do Século. São Paulo: Geração Editorial, 2001. p. 218-222.

SANTOS, Milton. Por uma Geografia Nova: Da Crítica da Geografia a uma Geografia Crítica. 6.ed. São Paulo: Edusp, 2008. 285 p.

SAVIANI, Dermeval. Educação: do senso comum à consciência filosófica. 18.ed. São Paulo: Autores Associados, 2009. 224 p.

SOARES, Maria Lúcia de Amorim. Girassóis ou Heliantos: maneiras criadoras para o conhecer geográfico. 1.ed. Sorocaba: Prefeitura Municipal, Prêmio Linc, 2001. $180 \mathrm{p}$.

VIGOTSKI, Lev S. Imaginação e criação na infância: ensaio psicológico: livro para professores. 1.ed. São Paulo, Ática, 2009. 135 p. 